\title{
Distribution of guanylate cyclase within photoreceptor outer segments
}

\author{
Mark A. Hallett ${ }^{1}$, Joan L. Delaat ${ }^{2}$, Kentaro Arikawa ${ }^{3}$, Cassandra L. Schlamp1, Fansheng Kong1 \\ and David S. Williams ${ }^{1,2, *}$ \\ ${ }^{1}$ School of Optometry, Indiana University, Bloomington, Indiana 47405, USA \\ 2Departments of Pharmacology and Neurosciences, UCSD School of Medicine, La Jolla, California 92093-0983, USA \\ ${ }^{3}$ Department of Biology, Yokohama City University, 22-2 Seto, Kanazawa-ku, Yokohama 236, Japan \\ *Author for correspondence (e-mail: dswilliams@ucsd.edu)
}

\section{SUMMARY}

Guanylate cyclases play an essential role in the recovery of vertebrate photoreceptor cells after light activation. Here, we have investigated how one such guanylate cyclase, RetGC-1, is distributed within light- and dark-adapted rod photoreceptor cells. Guanylate cyclase activity partitioned with the photoreceptor outer segment (OS) cytoskeleton in a light-sensitive manner. RetGC-1 was found to bind actin filaments in actin blot overlays, suggesting a mechanism for its association with the OS cytoskeleton. In retinal sections, this enzyme was immunodetected only in the OSs, where it appeared to be distributed throughout the disk membranes.

Key words: Photoreceptor cell, Guanylate cyclase, Actin, Immunocytochemistry

\section{INTRODUCTION}

Light activation of a vertebrate photoreceptor cell leads to hydrolysis of intracellular cyclic GMP and closure of the cyclic GMP-gated cation channels in the plasma membrane of the photoreceptor outer segment (reviewed by Lagnado and Baylor, 1992; Yarfitz and Hurley, 1994). Recovery from this response requires the synthesis of cyclic GMP by guanylate cyclase. Guanylate cyclase activity in the outer segments is sensitive to $\mathrm{Ca}^{2+}$ concentration (Lolley and Racz, 1982; Pepe et al., 1986; Koch and Stryer, 1988; Hakki and Sitaramayya, $1990)$, as a result of regulation by $\mathrm{Ca}^{2+}$-binding proteins, known as guanylate cyclase activating proteins (GCAPs). Two guanylate cyclases (Shyjan et al., 1992; Goraczniak et al., 1994; Lowe et al., 1995; Yang et al., 1995) and three GCAPs (Dizhoor et al., 1994, 1995; Gorczyca et al., 1994, 1995; Palczewski et al., 1994; Pozdnyakov et al., 1995) have now been identified in photoreceptor cells.

To understand fully how photoreceptor guanylate cyclase activity is regulated, it is essential to determine how the enzyme is distributed within the cell. From earlier studies it was thought that most of the guanylate cyclase activity is associated with the outer segment cytoskeleton and localized within the axoneme that connects the outer segment to the inner segment (Krishnan et al., 1978; Fleischmann and Denisevich, 1979; Fleischmann et al., 1980). Later studies developed procedures that resulted in solubilization of some of the guanylate cyclase activity, which could then be purified (Hakki and Sitaramayya, 1990; Horio and Murad, 1991; Hayashi and Yamazaki, 1991; Koch, 1991; Aparicio and Applebury, 1995). In addition, two immunocytochemical studies with primate retinas indicate that photoreceptor cell guanylate cyclase is not restricted to the axoneme (Dizhoor et al., 1994; Liu et al., 1994).

In the present study, we have examined the partitioning of guanylate cyclase and its immunolocalization within both light- and dark-adapted rod photoreceptor cells. We report on light-sensitive partitioning and suggest an explanation for the enzyme's detergent insolubility. We also describe the spatial distribution of the enzyme within the rod outer segment by comparing it with that of peripherin/rds, a protein found only in the disk rims (Molday et al., 1987; Arikawa et al., 1992).

\section{MATERIALS AND METHODS}

\section{Antibodies}

Monoclonal antibodies were made against actin-binding proteins in bovine photoreceptor outer segments (OSs). Dark-adapted OSs from 300 retinas were purified on sucrose gradients as described previously (Azarian et al., 1995). They were homogenized in buffer A plus $1 \%$ Triton X-100. Buffer A contained $20 \mathrm{mM}$ Tris-HCl, pH 7.5, $100 \mathrm{mM}$ $\mathrm{KCl}, 10 \mathrm{mM} \mathrm{MgCl}, 1 \mathrm{mM}$ ethylene glycol-bis ( $\beta$-aminoethyl ether $\mathrm{N}, \mathrm{N}, \mathrm{N}^{\prime}, \mathrm{N}^{\prime}$-tetraacetic acid) (EGTA), $1 \mathrm{mM}$ dithiothreitol (DTT), 1 $\mathrm{mM}$ phenylmethylsulfonyl fluoride (PMSF), $1 \mu \mathrm{M}$ pepstatin A (Boehringer-Mannheim, Indianapolis, IN), $24 \mu \mathrm{M}$ leupeptin (Boehringer-Mannheim, Indianapolis, IN) and $10 \mu \mathrm{g} / \mathrm{ml}$ phalloidin (Molecular Probes, Eugene, OR). All chemicals were purchased from Sigma Chemical Co., St Louis, MO, unless otherwise noted. After centrifugation at $361,000 \mathrm{~g}$ for 1 hour, the pellet was washed in the same buffer twice more. The final cytoskeletal pellet was extracted with buffer A plus $1 \mathrm{M} \mathrm{KCl}$. The resulting high-salt extract was dialyzed against buffer A, centrifuged at $361,000 \mathrm{~g}$ for 1 hour to remove any aggregates, incubated for 30 minutes on ice with $500 \mu \mathrm{g}$ of filamentous actin from rabbit back muscle in a volume of $25 \mathrm{ml}$ (buffer A plus $1 \mathrm{mM}$ ATP), and centrifuged again at $361,000 \mathrm{~g}$ for 1 
hour. After cosedimentation, the actin binding proteins were released from the actin filaments by incubation in buffer A plus $1 \mathrm{M} \mathrm{KCl}$, followed by centrifugation at $361,000 \mathrm{~g}$ for 1 hour. These actinbinding proteins $(100 \mu \mathrm{g}$ protein per injection) provided the antigen used for subcutaneous injection of Balb/c mice. Eye bleeds were taken after the second and third injections. Sera were screened using western blots of the antigen. A mouse with reactive sera (including reaction with a $115 \mathrm{kDa}$ polypeptide) was used to make monoclonal antibodies by conventional procedure. The spleen of the mouse was removed, teased apart and the cells rinsed in RPMI 1640 medium. Mouse myeloma cell line (P3 X 63AG88653) was fused with the spleen cells in $50 \%$ polyethylene glycol. The cells were rinsed in medium and plated at limiting dilution in microtitre plates with mouse peritoneal feeder cells. One clone recognized a $115 \mathrm{kDa}$ polypeptide, and was used to initiate the present study.

Polyclonal antibodies were made against the $115 \mathrm{kDa}$ polypeptide, which was identified as OS guanylate cyclase. Antibodies were made against the whole polypeptide, which was purified in denatured form by washing the Triton X-100-insoluble fraction (prepared as above) two times with $10 \mathrm{M}$ urea, $\mathrm{pH}$ 7. The resulting urea pellet was separated by SDS-PAGE and the polypeptide recognized by the monoclonal antibody was cut out of a Coomassie-blue stained gel. The gel was pulverized between two glass plates and injected (100 $\mu \mathrm{g}$ protein per injection) with adjuvant subcutaneously into the backs of Long Evans rats or New Zealand white rabbits.

Polyclonal antibodies were also made against a peptide corresponding to the last 10 amino acids of the bovine OS guanylate cyclase that appears to be the homologue of human RetGC-1 (Goraczniak et al., 1994). The peptide was synthesized as a multiple antigen peptide, or MAP (Tam, 1988), by the Indiana University School of Medicine (Indianapolis) Biochemistry Biotechnology Facility. The MAP was used as an immunogen to generate antisera in rats (as above) or in rabbits (standard protocol by Biosynthesis, Texas).

The polyclonal antibodies were affinity-purified by the method of Olmsted (1986). Briefly, a blot of antigen (isolated guanylate cyclase or MAP) on Immobilon-P was blocked with 5\% non-fat dry milk and 3\% BSA in Tris-buffered saline (TBS). Antiserum that was about 100 times more concentrated than that needed to detect the enzyme on the blot was incubated overnight with the Immobilon. The Immobilon was then rinsed with TBS and the antibody was eluted with $200 \mathrm{mM}$ glycine, $\mathrm{pH}$ 2.5. The $\mathrm{pH}$ was immediately neutralized with Tris base.

For immunolabelling of western blots and retinal sections by the polyclonal antibodies, negative control tests were routinely performed. Before use as a negative control, the affinity-purified antibody was incubated with a narrow strip of Immobilon-P, cut horizontally from western blots of heavily-loaded OS urea pellet or darkadapted OS Triton X-114 soluble fraction, so as to include polypeptides only with an apparent molecular mass of around $115 \mathrm{kDa}$. Alternatively, in the case of the peptide antibodies, the antibody was mixed with $0.1 \mathrm{mg} / \mathrm{ml}$ peptide in solution.

A sample of polyclonal antibody against guanylate cyclase that had been purified to homogeneity by column chromatography from bovine OSs was given to us by Dr Karl Koch (Koch, 1991). This antibody was used to label western blots for comparison with our antibodies. A monoclonal antibody against the $C$ terminus of rat peripherin/rds was a gift from Dr Bob Molday and used as in Arikawa et al. (1992).

\section{Immunolabelling western blots}

Proteins were separated by SDS-PAGE and transblotted at $4^{\circ} \mathrm{C}$ onto Immobilon-P (Millipore) in $25 \mathrm{mM}$ Tris- $\mathrm{HCl}, 192 \mathrm{mM}$ glycine, and $20 \%(\mathrm{v} / \mathrm{v}) \mathrm{MeOH}$, for 5 hours at $90 \mathrm{~V}$ or overnight at $40 \mathrm{~V}$. The membrane was blocked overnight with blocking buffer: $5 \%$ nonfat dry milk, $3 \%$ bovine serum albumin, and $0.05 \%$ sodium azide, in TBS $(8 \mathrm{~g} / \mathrm{l} \mathrm{NaCl}, 0.2 \mathrm{~g} / \mathrm{l} \mathrm{KCl}$, Tris-HCl, $\mathrm{pH} 7.5)$ and incubated with antibody for 2-16 hours. The blot was rinsed $4 \times 15$ minutes in TBS, incubated with secondary antibody conjugated to alkaline phos- phatase for 2 hours, and rinsed again. Color development was with NBT-BCIP.

\section{Peptide sequencing}

The same polypeptide from the OS urea pellet that was used as an immunogen (above) was transblotted on to Immobilon-P. It was sent to the Harvard Microchemistry Facility (Harvard University, Cambridge, MA). Under the supervision of Bill Lane, it was digested in situ with Lys-C and the resulting peptides separated by high pressure liquid chromatography. The sequences of the peptides in three of the major peaks were determined by Edman degradation.

\section{Actin blot overlays}

This protocol detects actin binding proteins by overlaying transblotted proteins with actin filaments, and then detecting where the actin filaments have bound by immunolabelling with an actin antibody. This protocol is a modified version of that described by Walker et al. (1984), who used it to test the actin binding ability of the acetylcholine receptor. Proteins were separated by SDS-PAGE and transferred to Immobilon-P. Many, though not all, proteins appear to renature and thus retain their binding properties after transfer to nitrocellulose or Immobilon (Carr and Scott, 1992). The membrane was blocked by incubation for 3-24 hours with 5\% non-fat dry milk and 3\% BSA in TBS. It was then incubated overnight in blot overlay buffer: $20 \mathrm{mM}$ Tris- $\mathrm{HCl}, \mathrm{pH} 7.5,130 \mathrm{mM} \mathrm{KCl}, 20 \mathrm{mM} \mathrm{NaCl}, 10 \mathrm{mM} \mathrm{MgCl}_{2}, 0.2$ $\mathrm{mM} \mathrm{CaCl}, 0.2 \mathrm{mM}$ ATP, $1 \mathrm{mg} / \mathrm{ml} \mathrm{BSA}, 10 \mu \mathrm{g} / \mathrm{ml}$ phalloidin and 10 $\mu \mathrm{g} / \mathrm{ml}$ actin filaments. The actin filaments were prepared from rabbit back skeletal muscle, as described by Pardee and Spudich (1982). After rinsing in TBS for $3 \times 15$ minutes, the blot was air dried for 46 hours. The blot was made wet again by brief immersion in ethanol, and then washed with TBS. It was incubated overnight with a monoclonal antibody against actin (made by Lin (1981), and provided by the Developmental Studies Hybridoma Bank), which was in turn detected with an alkaline phosphatase-conjugated secondary antibody. The color development was with nitro blue tetrazolium and 5-bromo-4-chloro-3-indoylphosphate.

\section{Guanylate cyclase activity assays}

Guanylate cyclase activity was measured in the Triton X-100insoluble fraction or the Triton X-114-soluble fraction of darkadapted bovine OSs, in the presence of different amounts of added actin filaments (from rabbit skeletal muscle, as above). To remove as much of the endogenous filamentous actin as possible from the Triton $\mathrm{X}$-100-insoluble fraction, we incubated the fraction with low salt buffer, $20 \mathrm{mM}$ Tris-HCl, pH 8, $0.5 \mathrm{mM}$ EGTA, $0.5 \mathrm{mM}$ DTT, for 30 minute at $37^{\circ} \mathrm{C}$, and, after centrifugation, discarded the supernatant (cf. Pardee and Spudich, 1982). The proteins were suspended in buffer $\mathrm{B}, 20 \mathrm{mM}$ Tris-HCl, pH 8, $1 \mathrm{mM}$ DTT $10 \mu \mathrm{g} / \mathrm{ml}$ phalloidin, and $0.1 \%$ Lubrol (ICN Biochemicals). The reaction was started by adding $2 \mathrm{mM}$ $\mathrm{MnCl}_{2}, 2 \mathrm{mM}$ GTP and $1 \mu \mathrm{Ci}\left[{ }^{3} \mathrm{H}\right] \mathrm{GTP}$ (New England Nuclear) in a final volume of $25 \mu \mathrm{l}$. After incubation at $30^{\circ} \mathrm{C}$, the reaction was stopped by adding EGTA, to give a concentration of $10 \mathrm{mM}$, and heating at $90^{\circ} \mathrm{C}$ for 5 minutes. The nucleotides were separated on PEIF-cellulose thin-layer chromatography (TLC) plates (Baker-flex) (Kavipurapu et al., 1982). A $1 \mu \mathrm{l}$ sample of each reaction was spotted on the TLC plate $3 \mathrm{~cm}$ from the bottom. After drying, $1 \mu \mathrm{l}$ of a nucleotide mix, $25 \mathrm{mM}$ each of GTP, GDP, GMP and cGMP, was added to the same spot and allowed to dry. The plate was developed with $600 \mathrm{mM} \mathrm{LiCl}$ for half the distance and $1 \mathrm{M} \mathrm{LiCl}$ for the remainder. When the solvent reached the top, $17 \mathrm{~cm}$ from the origin, the plate was viewed under long wavelength UV light. Nucleotides were seen as dark spots on a fluorescent background. Spots were cut out and counted in a scintillation counter. As the Triton X-100insoluble fraction contained insignificant phosphodiesterase activity, phosphodiesterase inhibitors were unnecessary. For assaying guanylate cyclase activity in the Triton X-114 soluble fraction, we followed the procedure of Gorczyca et al. (1994). In this procedure 
(Sp)GTP was used as a substrate, for the product, (Rp)cGMP, is not hydrolyzed by PDE.

A partially-pure fraction containing bovine GCAP-1 was given to us by Dr Alexander Dizhoor in Dr James Hurley's laboratory.

\section{Immunomicroscopy}

Guanylate cyclase was localized in sections of rat retinas. The advantage of using rat retinas, in contrast to bovine retinas, was that the animals could be maintained in a controlled light environment and that the retinas could be fixed immediately upon death. Long Evans rats were maintained on a 12 hour light/12 hour dark cycle. Dark adapted retinas were obtained 4 hours after lights-off, and lightadapted retinas were obtained 4 hours after lights-on. Retinas were also obtained from animals that had been exposed to 5 minutes of light 4 hours after lights-off, or placed in darkness for 5 minutes 4 hours after lights-on. The posterior segments of each eye were processed as described by Williams et al. (1990). Briefly, they were fixed in $4 \%$

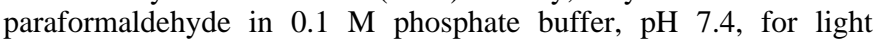
microscopy. For electron microscopy, the fixative contained $0.1-1 \%$ glutaraldehyde plus $2 \%$ paraformaldehyde. Thick $(7-10 \mu \mathrm{m})$ cryosections were prepared from OCT-embedded tissue, semithin $(0.5 \mu \mathrm{m})$ cryosections were prepared from sucrose-embedded tissue, and ultrathin sections were prepared from LR White-embedded tissue. Some cryosections were extracted briefly with detergent by incubating them for 5-10 minutes in buffer containing $0.5 \%$ Triton $\mathrm{X}-100$, $50 \mathrm{mM} \mathrm{NaCl}, 3 \mathrm{mM} \mathrm{MgCl} 2,200 \mathrm{mM}$ sucrose, $10 \mathrm{mM}$ Hepes, $\mathrm{pH}$ 7.4. The sections were blocked with $3 \%$ BSA in PBS, incubated with diluted primary antibodies in 1-3\% BSA in PBS overnight, washed $3 \times 10$ minutes in PBS, incubated with the appropriate secondary antibody conjugated to Texas Red (for immunofluorescence) or colloidal gold (for electron microscopy), and washed again with PBS.
In some cases, sequential sections were labelled with the different guanylate cyclase antibodies or with a guanylate cyclase antibody and anti-peripherin/rds, so that labelling patterns could be more readily compared.

\section{RESULTS}

\section{Antibodies against OS guanylate cyclase}

Using a mixture of bovine OS actin-binding proteins as an immunogen, we isolated a hybridoma cell line producing an antibody that recognized a $115 \mathrm{kDa}$ polypeptide on western blots of bovine OS proteins (Fig. 1A, lane 2). The antibody also recognized a polypeptide with slightly greater mobility in rat OSs (Fig. 1A, lane 1). Although the immunogen was prepared from a high salt extract of the detergent-insoluble fraction of OSs (followed by desalting and binding to actin filaments), the recognized $115 \mathrm{kDa}$ polypeptide was actually more enriched in the fraction that remained insoluble after bovine OSs had been washed in buffer containing 2\% Triton $\mathrm{X}-100$, and then buffer containing $6 \mathrm{M}$ urea (lane 5, Fig. 1B). The polypeptide was purified from this urea-insoluble fraction and used to generate a polyclonal antibody, which showed greater specificity than the monoclonal antibody. The $115 \mathrm{kDa}$ polypeptide recognized by the antibodies appeared to be guanylate cyclase, based on two criteria. Firstly, its labelling on western blots of various OS fractions by our antibodies and an antibody from Dr K. Koch, which was made against guanylate cyclase purified by column chromatography from
A

B

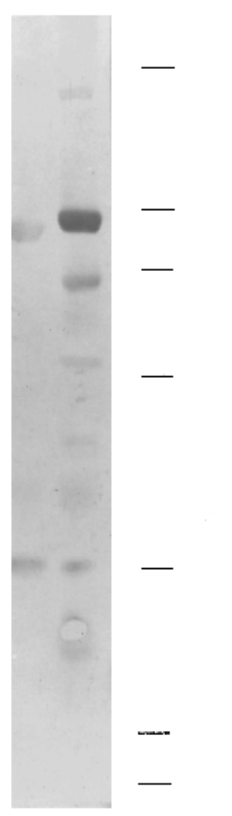

C TS TP US UP

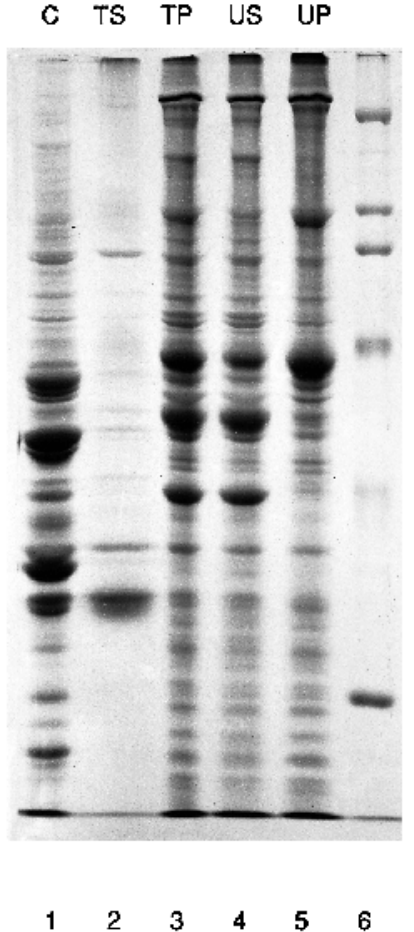

1
C TS TP US UP

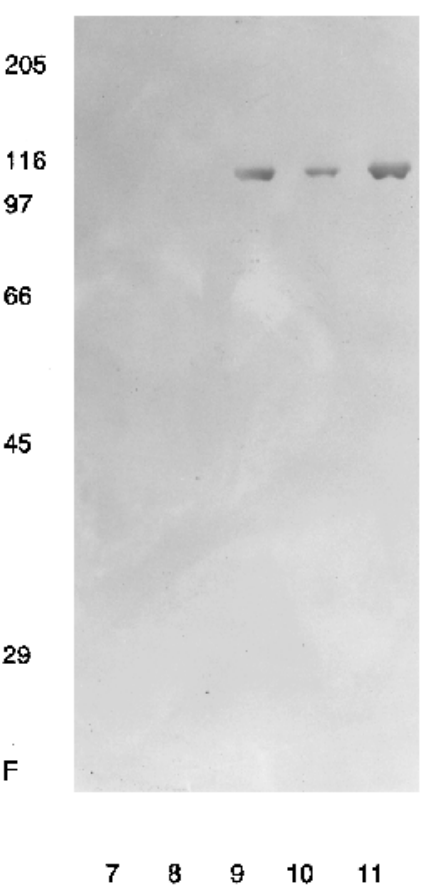

C

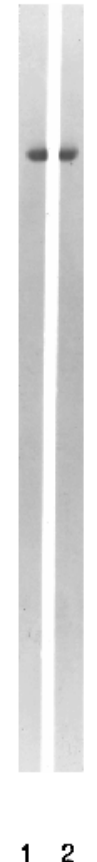

Fig. 1. OS guanylate cyclase (115 $\mathrm{kDa}$ polypeptide) in different OS fractions and its detection by different antibodies. (A) Western blot of Triton X100-insoluble fraction of rat (lane 1) and bovine (lane 2) OSs, immunolabelled with monoclonal antibody. Relative positions of same molecular mass standards as in lane 6, part $\mathrm{B}$, are indicated on the right.

(B) Coomassie blue-stained gel (lanes 1-6) and western blot (lanes 7-11) of different fractions of dark-adapted bovine OSs. The western blot was immunolabelled with affinitypurified polyclonal antibody generated against urea-insoluble guanylate cyclase. OSs were homogenized in buffer A to yield the cytosolic fraction $(\mathrm{C}$, lanes 1 and 7). The membrane pellet was washed twice more and then extracted with buffer A plus 3\% Triton $\mathrm{X}-100$ to yield lanes 2 and 8 (TS). The detergent-insoluble fraction was

washed twice more (TP, lanes 3 and 9), and then extracted with $6 \mathrm{M}$ urea, $\mathrm{pH} \mathrm{7,} \mathrm{to} \mathrm{yield} \mathrm{lanes} 4$ and 10 (US). The urea pellet (UP) was then washed two more times (lanes 5 and 11). Lane 6 shows molecular mass standards (in kDa). (C) Western blot of bovine OS proteins immunolabelled with the antibody used in B (lane 1) and an antibody that was made against homogeneous guanylate cyclase from bovine OSs by Dr Karl Koch (lane 2). The proteins were separated in a single lane on a gel. The lane was then cut in half lengthwise after transblotting to give lanes 1 and 2. 


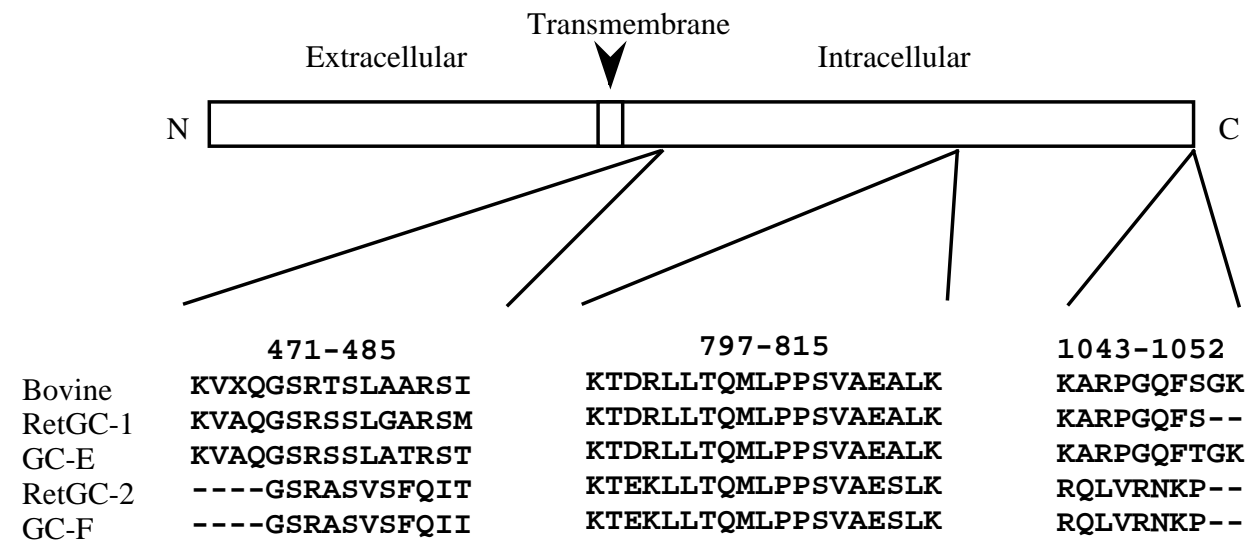

Fig. 2. Domain structure of guanylate cyclase, illustrating the regions to which the sequenced peptides we obtained from the bovine OS $115 \mathrm{kDa}$ polypeptide correspond (cf.

Goraczniak et al., 1994). Amino acid sequences were determined from three peptides released by Lys-C digestion of the polypetide. Designation of lysine as the first amino acid of each peptide follows from the use of Lys-C to generate the peptides. The identity of the other amino acids was determined from Edman degradation. $\mathrm{X}$ indicates that the identity of the amino acid was not clear. For comparison, the corresponding

sequences of human RetGC-1 and RetGC-2 and rat GC-E and GC-F are shown below the bovine peptide sequences we obtained. Amino acid numbers refer to bovine sequence (Goraczniak et al., 1994). Alignment of bovine OS guanylate cyclase with human RetGC-1 from Goraczniak et al. (1994); alignment of human RetGC-2 with human RetGC-1 from Lowe et al. (1995); corresponding sequences of rat GC-E and GC-F were obtained from Yang et al. (1995). Dashes indicate no corresponding residues with these alignments (the bovine sequence and rat GC-E contain two additional amino acids at their $\mathrm{C}$ termini).

A

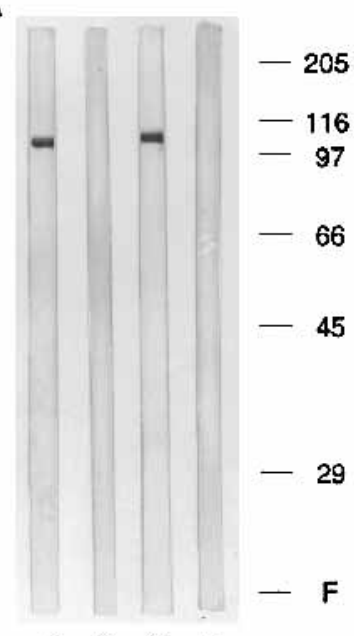

$\begin{array}{llll}1 & 2 & 3 & 4\end{array}$

B

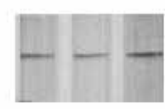

123
Fig. 3. Western blots of rat retinal proteins immunolabelled with affinity-purified antibodies against bovine OS guanylate cyclase; these antibodies were used for immunolabelling of rat retinal sections. (A) Test for specific labelling of guanylate cyclase. Lane 1, polyclonal antibody against whole protein. Lane 2, as for lane 1, except antibody was preincubated with guanylate cyclase on

Immobilon-P. Lane 3, antibody made in rat against $\mathrm{C}$-terminal peptide. Lane 4, as for lane 3, except that $0.1 \mathrm{mg} / \mathrm{ml} \mathrm{C}$ terminal peptide was included with antibody. Positions of molecular mass standards $(\mathrm{kDa})$ and dye front $(\mathrm{F})$ are indicated on left. (B) Comparison of labelling by the two antibodies. Lane 1, polyclonal antibody against whole protein. Lane 3, antibody made against $\mathrm{C}$ terminal peptide. Lane 2, both antibodies mixed 50:50. A single band is evident in all lanes, including lane 2. The same result was found with western blots of bovine OS proteins. In B, the western blot was not cut into strips. Instead separate lanes were effected by creating isolated channels on the blot surface with a plexiglass clamp apparatus; the different antibodies and the washing solutions were pipetted into these channels.

bovine OSs (Koch, 1991), was the same (Fig. 1C). Secondly, partial sequence data, obtained from the immunogen used to generate the polyclonal antibody, corresponded to regions of the sequence of the bovine retinal guanylate cyclase, cloned and described by Goraczniak et al. (1994) (Fig. 2). This bovine enzyme appears to be the homologue of RetGC-1 in human

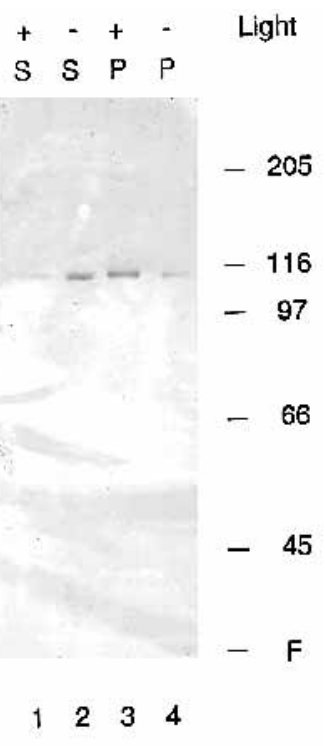

Fig. 4. Western blot of dark- and light-adapted bovine OSs solubilized in buffer containing Triton X-114, and then centrifuged at high speed. The blot was labelled with anti-guanylate cyclase. Lanes 1 and 2 contain the soluble proteins from light- and dark-adapted OSs, respectively. Lanes 3 and 4 contain the insoluble proteins from lightand dark-adapted OSs, respectively.

retina (Shyjan et al., 1992) and GC-E in rat retina (Yang et al., 1995) (Fig. 2).

Additional antisera were raised successfully against the bovine C-terminal peptide shown in Fig. 2. Resulting affinitypurified peptide antibodies immunolabelled western blots of different bovine OS fractions in the same manner as the polyclonal antibody against the whole protein (cf. Fig. 1B, lanes 711), providing further evidence that the latter recognizes guanylate cyclase.

The antibody against the whole protein and one of the antibodies against the $\mathrm{C}$-terminal peptide were found to be most suitable for labelling sections of rat retinas (see below). These affinity-purified antibodies reacted specifically with a single polypeptide on western blots of rat OSs (Fig. 3A). Both labelled the same polypeptide (Fig. 3B). Examination of the Cterminal sequences of the two retinal guanylate cyclases (Fig. 2 ), indicates that this recognized polypeptide is the RetGC1/GC-E form of guanylate cyclase (which we will call RetGC- 


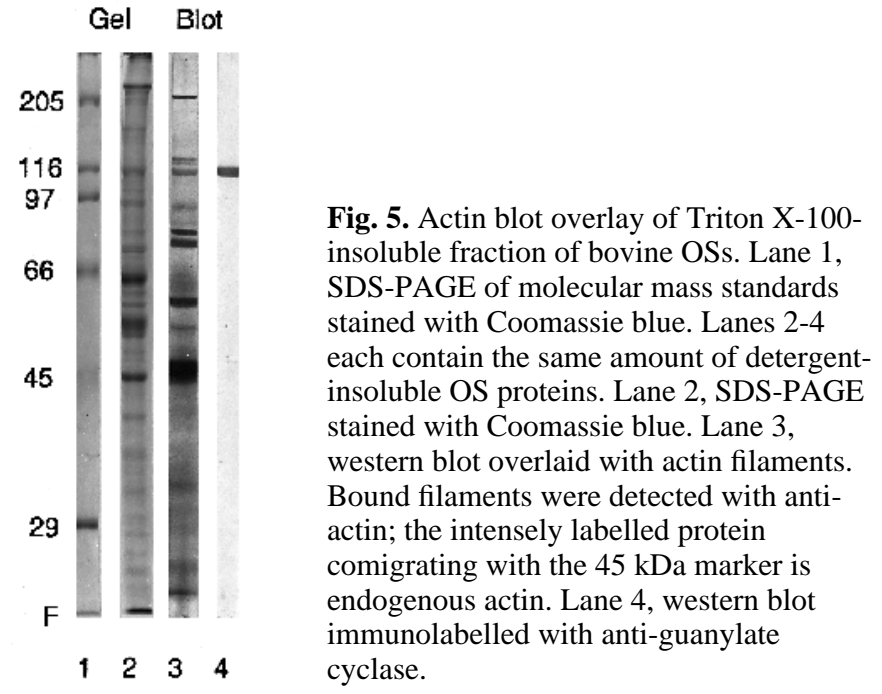

1; cf. Lowe et al., 1995; Yang et al., 1995). RetGC-2 migrates slightly faster than RetGC-1 in SDS-PAGE (Lowe et al., 1995).

\section{Detergent insolubility}

In early studies it was found that nearly all of the OS guanylate cyclase activity was associated with a detergent-insoluble fraction, which consisted mainly of OS axonemes (Krishnan et al., 1978; Fleischmann and Denisevich, 1979; Fleischmann et al., 1980). As illustrated in Fig. 1B, our studies also show that most of the enzyme is insoluble, even in urea. Nevertheless, protocols have now been designed for the chromatographic purification of OS guanylate cyclase, in which washing the OS cytoskeleton with buffer containing a combination of detergent and high salt concentration, such as $5 \%(\mathrm{v} / \mathrm{v})$ dodecyl- $\beta-\mathrm{D}-$ maltoside and $1 \mathrm{M} \mathrm{KCl}$, results in extraction of a portion of the enzyme activity (Hayashi and Yamazaki, 1991; Koch, 1991). Most recently, guanylate cyclase was obtained after solubilization of OS membranes in 1.5\% dodecyl- $\beta$-D-maltoside and $50 \mathrm{mM} \mathrm{NaCl}$ (Aparicio and Applebury, 1995). We found

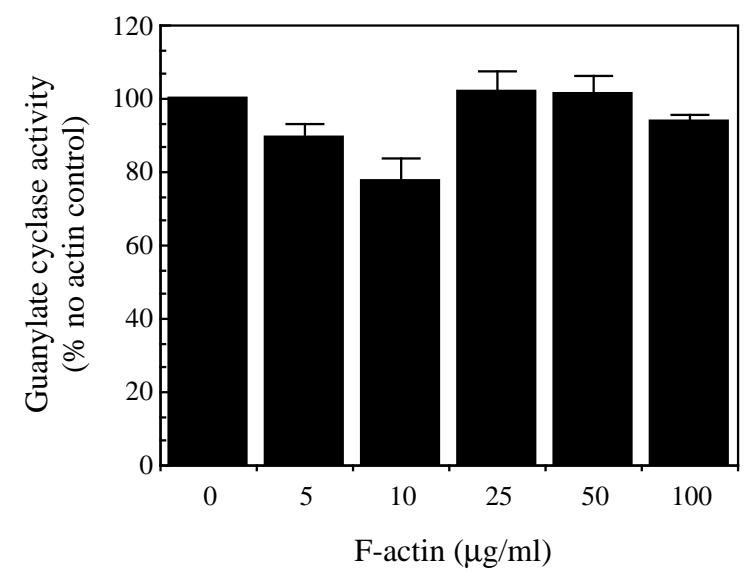

Fig. 6. Guanylate cyclase activity in the Triton X-100-insoluble fraction of bovine OSs, measured as a function of added filamentous actin. Activity is shown as a percentage of that without additional actin filaments.

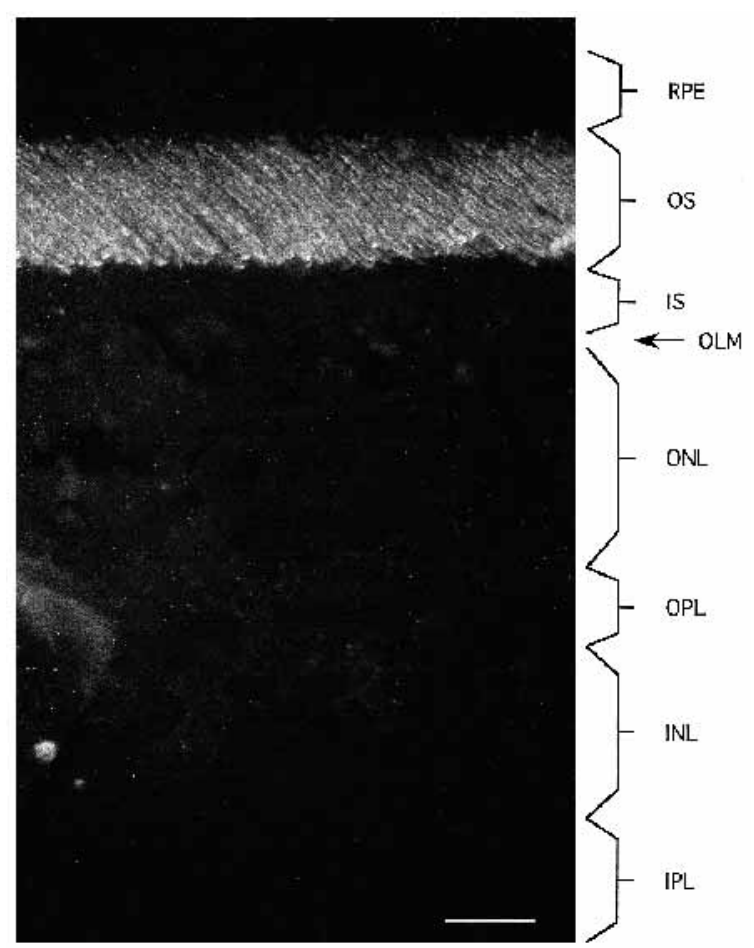

Fig. 7. Immunofluorescence of $0.5 \mu \mathrm{m}$ cryosection of rat retina, labelled with anti-guanylate cyclase. Prior to labelling the section was incubated briefly in buffer containing $0.5 \%$ Triton X-100.

Retinal pigmented epithelium (RPE), outer segments (OS), inner segments (IS), outer limiting membrane (OLM), outer nuclear layer (ONL), outer plexiform layer (OPL), inner nuclear layer (INL), inner plexiform layer (IPL). Bar, $20 \mu \mathrm{m}$.

that homogenization of dark-adapted bovine OSs in ice-cold buffer containing 3\% Triton X-114 and $100 \mathrm{mM} \mathrm{KCl}$ resulted in solubilization of most of the guanylate cyclase. Interestingly, if the OSs were first exposed to 10 minutes of light, the guanylate cyclase was mostly insoluble (Fig. 4), indicating that light exposure affects the partitioning of the enzyme with the OS cytoskeleton.

\section{Binding to actin filaments}

Because we had obtained a monoclonal antibody against guanylate cyclase using OS actin-binding proteins as the immunogen, it seemed that the enzyme might associate with the OS cytoskeleton as a result of binding to actin filaments. To test if OS guanylate cyclase could bind directly to actin filaments, we performed 'actin blot overlays' with insoluble OS fractions. Western blots containing proteins of these fractions were incubated with actin filaments, and the proteins that bound the actin filaments were identified by immunolabelling the blots with actin antibodies. One of the identified actin binding proteins has the same mobility as guanylate cyclase (Fig. 5), suggesting that the enzyme can bind directly to actin filaments. Guanylate cyclase from both light- and darkadapted OSs appeared to bind actin filaments to the same extent.

To see if any effect of actin filaments on guanylate cyclase activity could be detected, we measured the activity of the Triton X-100-insoluble OS fraction, in the presence of different concentrations of actin filaments. Although the 

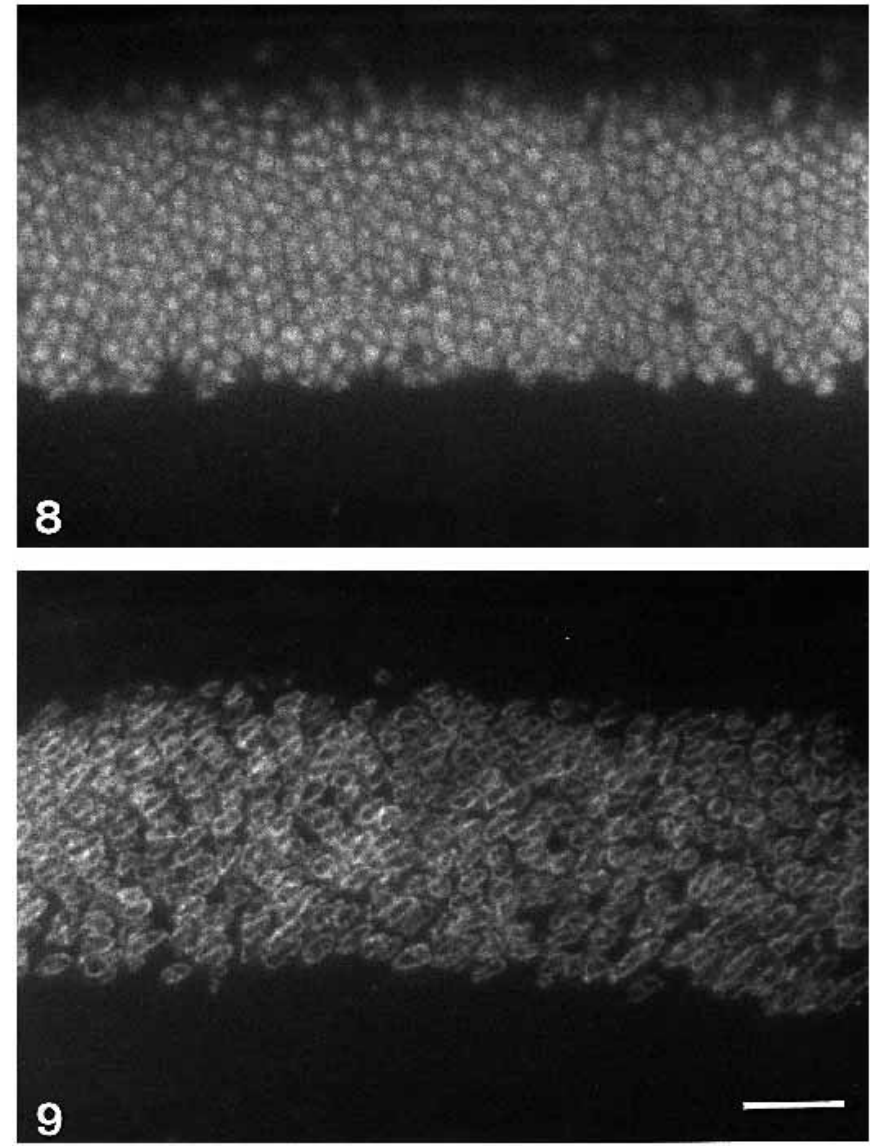

Fig. 8. Immunofluorescence of $0.5 \mu \mathrm{m}$ cryosection of rat retina, labelled with anti-guanylate cyclase. ROSs are shown in oblique section and are labelled throughout. Same magnification as Fig. 9. Fig. 9. Immunofluorescence of $0.5 \mu \mathrm{m}$ cryosection of rat retina, labelled with anti-peripherin/rds. ROSs are shown in oblique section and are labelled only around their periphery. Bar, $10 \mu \mathrm{m}$.

fraction was washed first with low salt buffer to extract endogenous actin (cf. Pardee and Spudich, 1982; Pinder and Gratzer, 1983), a significant portion could not be extracted, resulting in about $1 \mu \mathrm{g} / \mathrm{ml}$ endogenous actin in all samples assayed. The addition of up to $100 \mu \mathrm{g} / \mathrm{ml}$ filamentous actin had no effect on guanylate cyclase activity (Fig. 6). The same negative result was found irrespective of whether light- or dark-adapted OSs were used. Similarly, we did not detect any effect of $100 \mu \mathrm{g} / \mathrm{ml}$ filamentous actin on guanylate cyclase activity in a Triton X-114-soluble fraction of dark-adapted OSs. The urea-insoluble fraction could not be used for these tests as exposure to urea abolished guanylate cyclase activity. In both the Triton X-100-insoluble fraction and the Triton X114-soluble fraction, we measured basal guanylate cyclase activity. Guanylate cyclase activity in OS membranes is enhanced greatly by the addition of guanylate cyclase activating protein (GCAP) in low $\mathrm{Ca}^{2+}$ concentrations (Dizhoor et al., 1994). We therefore attempted to test the ability of partiallypure bovine GCAP-1 to activate guanylate cyclase in the Triton $\mathrm{X}-100$-insoluble OS fraction and in the Triton X-114-soluble OS fraction. Despite being able to activate guanylate cyclase in OS membranes that had been extensively washed in low ionic strength buffer, this GCAP-1 preparation had no effect

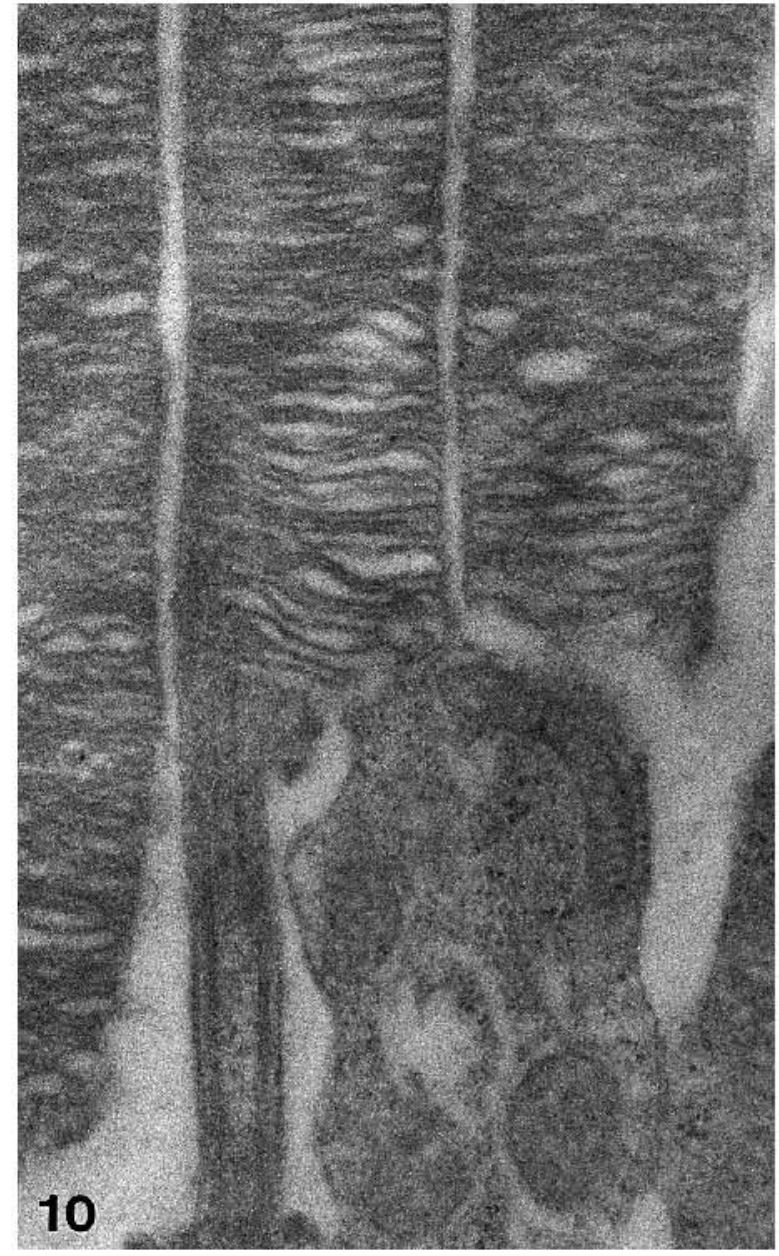

Fig. 10. Electron micrograph of an ultrathin section of rat retina, immunogold labelled by anti-guanylate cyclase that had been preincubated with Immobilon containing purified guanylate cyclase. This control section was labelled in parallel with those shown in Figs 11 and 12. Significant label is not evident over any structure. Same magnification as Fig. 12.

on guanylate cyclase activity in these detergent-treated fractions, so that we were unable to test for any effect of actin filaments on GCAP-stimulated guanylate cyclase activity.

\section{Immunomicroscopic localization of guanylate cyclase}

Affinity-purified polyclonal antibodies against the whole protein and against the $\mathrm{C}$-terminal peptide were used to localize the RetGC-1 homologue of guanylate cyclase in retinal sections. Rat retinas (in contrast to bovine retinas) were used for these immunomicroscopical studies as they could be fixed under controlled lighting and circadian conditions. By immunofluorescence microscopy of thick $(7 \mu \mathrm{m})$ and semithin $(0.5 \mu \mathrm{m})$ cryosections, guanylate cyclase was detected only in the OS layer (Fig. 7), which in rats consists of nearly all rod photoreceptor outer segments (ROSs). Both antibodies gave the same labelling pattern. No difference was detected between the labelling of light- and dark-adapted retinas. Prior incubation of the antibodies with isolated guanylate cyclase (on western blots), or, in the case of the peptide antibodies, with 

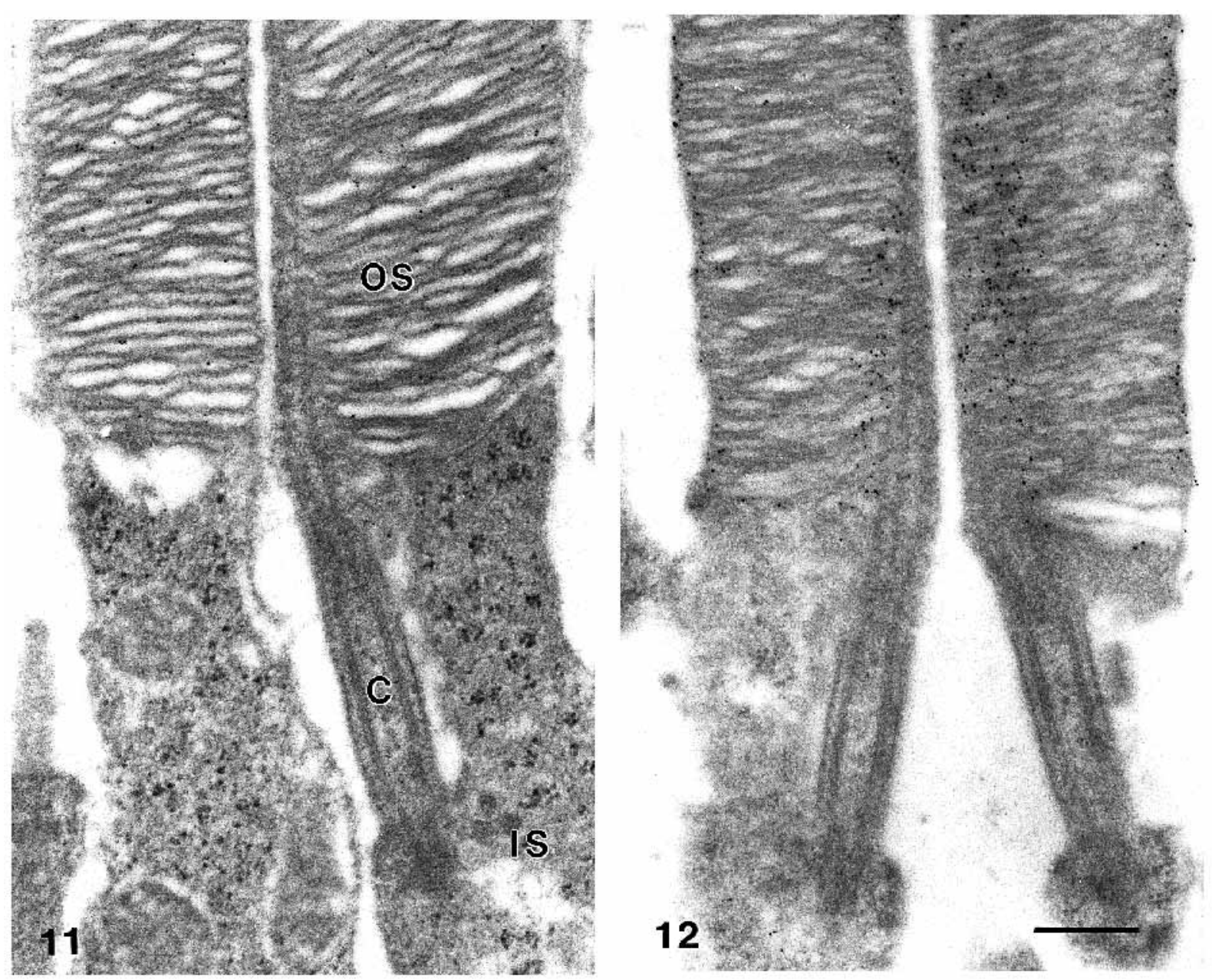

Fig. 11. Electron micrograph of an ultrathin section of rat retina, immunogold labelled by anti-guanylate cyclase. Label is evident over all the disk membranes of the rod outer segments (OS), but is absent from the connecting cilium (C) and the inner segment (IS). Same magnification as Fig. 12.

Fig. 12. Electron micrograph of an ultrathin section of rat retina, immunogold labelled by anti-peripherin/rds. Label is restricted to the margins of the disk membranes of the ROSs. Label is more widespread on one side of each ROS probably because of labelling of an incisure (cf. Molday et al., 1987). Bar, $0.5 \mu \mathrm{m}$.

$0.1 \mathrm{mg} / \mathrm{ml}$ peptide, abolished the labelling. In sections that were incubated with buffer containing $0.5 \%$ Triton X-100 for 5-10 minutes before the addition of the antibody, labelling appeared to be greater along the margins of the ROSs (note streaky appearance of label in Fig. 7). To determine if guanylate cyclase might be distributed preferentially at the periphery of the ROSs (perhaps restricted to the plasma membrane), we compared the immunolabelling of guanylate cyclase and peripherin/rds in oblique sections of the outer segments that had not been pretreated with detergent. Peripherin/rds is located in the disk rims (Molday et al., 1987; Arikawa et al., 1992). As can be seen by comparing Figs 8 and 9 , the entire ROS profile is filled by guanylate cyclase label, whereas the peripherin/rds labelling pattern of each ROS appears like an annulus, with the central part unlabelled.

The same affinity-purified antibodies were used for immunogold labelling of ultrathin sections (Figs 10 and 11). By electron microscopy label was found over the entire ROS section, with the exception of the connecting cilium. Consistent with the immunofluorescence images of thicker sections, the inner segment was also not labelled (Fig. 11). Although the intensity of the gold label was not as great as we have encountered with antibodies against a number of other ROS proteins, it appeared to be specific, for sections exposed to antibody that had been preincubated with immunoblotted guanylate cyclase were not labelled (Fig. 10). Moreover, the guanylate cyclase labelling pattern of the ROS disks contrasted with peripherin/rds labelling. Fig. 12 shows an electron micrograph of ROSs labelled anti-peripherin/rds. The section was from the same block as the sections in Figs 10 and 11, and the three were labelled in parallel. However, peripherin/rds label is limited to the margins of each ROS.

\section{DISCUSSION}

Guanylate cyclase activity has been found previously to partition with the OS cytoskeleton (Krishnan et al., 1978; Fleischmann and Denisevich, 1979; Fleischmann et al., 1980). In the present study, we have used antibodies to detect the 
bovine and rat homologues of RetGC-1, which is one of two transmembrane guanylate cyclases found in human photoreceptor cells (Lowe et al., 1995). Consistent with the earlier studies, we observed by western blot analysis that this enzyme partitioned with the OS cytoskeleton. In addition, we noted that this partitioning was affected by light. Horio and Murad (1991) had observed that less guanylate cyclase activity was extracted by $1 \mathrm{M} \mathrm{KCl}$ plus Triton X-100 or Lubrol PX if the OSs were bleached. We also found that the enzyme can bind directly to actin filaments. As actin filaments form part of the OS cytoskeleton, this binding suggests a mechanism for the association of the enzyme with the cytoskeleton. Nevertheless, it cannot account for its insolubility in urea, for urea extracts actin filaments. Here insolubility is most likely due to aggregation of denatured enzyme; enzyme activity was destroyed by urea.

The ability of OS guanylate cyclase to bind actin filaments may have physiological consequences. It could be important for docking the enzyme or influencing its activity. An example of another transmembrane enzyme that has been reported to bind actin filaments is the EGF receptor (Hartigh et al., 1992). It is estimated that only $5 \%$ of this receptor is bound, but that which is bound has a higher affinity for EGF (Van Bergen en Henegouwen et al., 1989; Wiegant et al., 1986). Our studies found that actin filaments had no effect on basal guanylate cyclase activity, but the possibility of an effect on GCAP-stimulated activity remains to be tested.

There have been two previous reports on the immunolocalization of guanylate cyclase in retinas, both using primate retinas. Dizhoor et al. (1994) described immunofluorescence of thick retinal sections, and showed that RetGC-1 was in the outer segments, and possibly the inner segments of human photoreceptor cells. Liu et al. (1994) reported results from electron immunomicroscopy of monkey and human retinas. Both groups found labelling of RetGC-1 in both cone and rod photoreceptor cells, with more intense labelling in cones. In the present study, we investigated the localization of this enzyme in the rat retina, which contains very few cone cells, so that we have not addressed any differences between rods and cones.

Focusing on the subcellular localization within the rod photoreceptor cells, we find that our results are not entirely consistent with those of Liu et al. (1994). We agree in that the connecting cilium was not labelled, but disagree in two other respects. Firstly, Liu et al. show immunolabelling in the inner segments as well as the outer segments, whereas all of our antibodies labelled only the outer segments. Secondly, they reported greater labelling at the periphery of the outer segments. RetGCs belong to the guanylate cyclase membrane receptor family (Shyjan et al., 1992; Lowe et al., 1995). Such guanylate cyclases have an intracellular protein kinase-like domain and cyclase catalytic domain, a single transmembrane domain, and an extracellular ligand-binding domain (Garbers and Lowe, 1994). Although no extracellular ligand has yet been defined for RetGCs, if they were regulated by one, like the other members of the family, they might be expected to be restricted to the plasma membrane of the ROS, which would effect a peripheral labelling pattern. In our hands, the periphery of the ROSs retained more immunoreactive guanylate cyclase after detergent treatment, but without detergent extraction, the enzyme was found throughout the outer segment, in contrast to peripherin/rds. Therefore, our results indicate that RetGC-1 is localized throughout the disk membranes. Retention of guanylate cyclase in the periphery after detergent extraction might be due to association of the enzyme in the disk rim or plasma membrane with the cytoskeleton, or association of the enzyme in the plasma membrane with insoluble components of the extracellular matrix. Given that the protein composition of the ROS plasma membrane and the ROS disk membranes are quite different (Molday and Molday, 1987), it is plausible, however, that RetGC-1 might be absent from the plasma membrane (immunoelectron microscopy of tissue sections does not provide sufficient resolution to determine if this is true).

It is unclear why our results differ from those of Liu et al. (1994). It could be due to inherent differences between primate photoreceptors and those of rats. It is worth noting, however, that we found the same labelling with an antibody against the whole protein as well as an antibody against a C-terminal peptide; the results of Liu et al. were obtained with a single peptide antibody. Moreover, we were able to assess the question of peripheral outer segment distribution by comparing the labelling with that of peripherin/rds, which is known to be located only in the disk rims and thus provides a positive control for peripheral labelling.

What is the functional significance of the distribution of guanylate cyclase throughout the ROS disk membranes, rather than around the periphery of the ROS? The answer to this question should become clearer with further studies on the biochemical regulation of guanylate cyclase. Perhaps it is pertinent that localization of guanylate cyclase in the ROS disk membranes more closely coincides with the distribution of the GCAPs, which are soluble proteins concentrated in the OSs (Dizhoor et al., 1995; Gorczyca et al., 1994, 1995). A consequence of this guanylate cyclase localization is that it places the extracellular domain of the enzyme in the intradiskal space, where it cannot be exposed to extracellular ligands.

The immunolocalization of guanylate cyclase appears difficult to reconcile with its actin-binding property and the reported distribution of actin filaments. A domain of actin filaments has been described in the connecting cilium between the inner and outer segment (see Williams, 1991, for review). Ironically, this was the one domain of the outer segment that was not labelled by guanylate cyclase antibodies. It is of course possible that immunoreactive sites are masked in this region (perhaps due to actin binding). Note that even opsin, the major protein of ROS disk and plasma membranes, is often immunolabelled poorly or not at all in the plasma membrane of the connecting cilium (cf. Nir and Papermaster, 1983; Nir et al., 1984; Besharse et al., 1985; Hicks and Molday, 1986; Usukura and Bok, 1987; Röhlich et al., 1989), possibly as a result of epitope masking in this region (Besharse et al., 1985; Bok, 1985; Miyaguchi and Hashimoto, 1992). Likewise, in our studies of peripherin/rds, including the present one, peripherin/rds labelling was not detectable in the connecting cilium (Fig. 12). A second possibility is that actin filaments are present elsewhere in the outer segment, but have yet to be detected. The procedures used to visualize the spectrin-actin cytoskeleton underlying the erythrocyte plasma membrane (Byers and Branton, 1985; Liu et al., 1987; Derick et al., 1992), for example, have not been applied to ROSs. Interestingly, detergent-extraction of retinal sections resulted in selective 
retention of guanylate cyclase near the outer segment plasma membrane, which would be consistent with binding of guanylate cyclase to the cytoskeleton in this region.

In conclusion, the guanylate cyclase, RetGC-1, partitions with the OS cytoskeleton in a light-sensitive manner, possibly due to its ability to bind actin filaments. The enzyme is restricted solely to the outer segment, where it is distributed throughout the disk membranes.

We are grateful to Dr Karl Koch for a sample of his guanylate cyclase antibody, Drs Sasha Dizhoor and Jim Hurley for the GCAP fraction, Dr Bob Molday for the peripherin/rds antibody, and the Developmental Studies Hybridoma Bank (supported by NIH contract N01-HD-6-2915) for the actin antibody. The work was supported by NIH grant EY 07042 to D.S.W.

\section{REFERENCES}

Aparicio, J. G. and Applebury, M. L. (1995). The bovine photoreceptor outer segment guanylate cyclase: purification, kinetic properties, and molecular size. Prot. Express. Purif. 6, 501-511.

Arikawa, K., Molday, L. L., Molday, R. S. and Williams, D. S. (1992). Localization of peripherin/rds in the disk membranes of cone and rod photoreceptors: relationship to disk membrane morphogenesis and retinal degeneration. J. Cell Biol. 116, 659-667.

Azarian, S. M., King, A. J., Hallett, M. A. and Williams, D. S. (1995). Selective proteolysis of arrestin by calpain: molecular characterization and its effect on rhodopsin dephosphorylation. J. Biol. Chem. 270, 24375-24384.

Besharse, J. C., Forestner, D. M. and Defoe, D. M. (1985). Membrane assembly in retinal photoreceptors. III. Distinct membrane domains of the connecting cilium of developing rods. J. Neurosci. 5, 1035-1048.

Bok, D. (1985). Retinal photoreceptor-pigment epithelium interactions. Invest. Ophthalmol. Vis. Sci. 26, 1659-1694.

Byers, T. J. and Branton, D. (1985). Visualization of the protein associations in the erythrocyte membrane skeleton. Proc. Nat. Acad. Sci. USA 82, 61536157

Carr, D. W. and Scott, J. D. (1992). Blotting and band-shifting: techniques for studying protein-protein interactions. Trends Biochem Sci. 17, 246-249.

Derick, L. H., Liu, S., Chishti, A. H. and Palek, J. (1992). Protein immunolocalization in the spread erythrocyte. Eur. J. Cell Biol. 57, 317-320.

Dizhoor, A. M., Lowe, D. G., Olshevskaya, E. V., Laura, R. P. and Hurley, J. B. (1994). The human photoreceptor membrane guanylyl cyclase, RetGC, is present in outer segments and is regulated by calcium and a soluble activator. Neuron 12, 1345-1352.

Dizhoor, A. M., Olshevskaya, E. V., Henzel, W. J., Wong, S. C., Stults, J. T., Ankoudinova, I. and Hurley, J. B. (1995). Cloning, sequencing, and expression of a $24 \mathrm{kDa}$ Ca plus-binding protein activating photoreceptor guanylyl cyclase. J. Biol. Chem. 270, 25200-25206.

Fleischman, D. and Denisevich, M. (1979). Guanylate cyclase of isolated bovine retinal rod axonemes. Biochemistry 18, 5060-5066.

Fleischman, D., Denisevich, M., Raveed, D. and Pannbacker, R. G. (1980). Association of guanylate cyclase with the axoneme of retinal rods. Biochim. Biophys. Acta 630, 176-186.

Garbers, D. L. and Lowe, D. G. (1994). Guanylyl cyclase receptors. J. Biol. Chem. 269, 30741-30744.

Goraczniak, R. M., Duda, T., Sitaramayya, A. and Sharma, R. K. (1994) Structural and functional characterization of the rod outer segment membrane guanylate cyclase. Biochem. J. 302, 455-461.

Gorczyca, W. A., Gray-Keller, M. P., Detwiler, P. B. and Palczewski, K. (1994). Purification and physiological evaluations of a guanylate cyclase activating protein from retinal rods. Proc. Nat. Acad. Sci. USA 91, 40144018.

Gorczyca, W. A., Polans, A. S., Surgucheva, I. G., Subbaraya, I., Baehr, W. and Palczewski, K. (1995). Guanylyl cyclase activating protein. J. Biol. Chem. 270, 22029-22036.

Hakki, S. and Sitaramayya, A. (1990). Guanylate cyclase from bovine rod outer segments: Solubilization, partial purification, and regulation by inorganic pyrophosphate. Biochemistry 29, 1088-1094.

Hartigh, J. C., van Bergen en Henegouwen, P. M. P., Verkleij, A. J. and Boonstra, J. (1992). The EGF receptor is an actin-binding protein. J. Cell Biol. 119, 349-355.
Hayashi, F. and Yamazaki, A. (1991). Polymorphism in purified guanylate cyclase from vertebrate rod photoreceptors. Proc. Nat. Acad. Sci. USA 88, 4746-4750.

Hicks, D. and Molday, R. S. (1986). Differential immunogold-dextran labeling of bovine and frog rod and cone cells using monoclonal antibodies against bovine rhodopsin. Exp. Eye Res. 42, 55-71.

Horio, Y. and Murad, F. (1991). Solubilization of guanylyl cyclase from bovine rod outer segments and effects of lowering $\mathrm{Ca}^{2+}$ and nitro compounds. J. Biol. Chem. 266, 3411-3415.

Kavipurapu, P., Farber, D. and Lolley, R. (1982). Degradation and resynthesis of cyclic $3^{\prime}, 5^{\prime}$-guanosine monophosphate in truncated rod photoreceptors from bovine retina. Exp. Eye Res. 34, 181-189.

Koch, K.-W. and Stryer, L. (1988). Highly cooperative feedback control of retinal rod guanylate cyclase by calcium ions. Nature 344, 64-66.

Koch, K.-W. (1991). Purification and identification of photoreceptor guanylate cyclase. J. Biol. Chem. 266, 8634-8637.

Krishnan, N., Fletcher, R. T., Chader, G. J. and Krishna, G. (1978). Characterization of guanylate cyclase of rod outer segments of the bovine retina. Biochim. Biophys. Acta 523, 506-515.

Lagnado, L. and Baylor, D. (1992). Signal flow in visual transduction. Neuron 8, 995-1002.

Lin, J. J. C. (1981). Monoclonal antibodies against myofibrillar components of rat skeletal muscle decorate the intermediate filaments of cultured cells. Proc. Nat. Acad. Sci. USA 78, 2335-2339.

Liu, S., Derick, L. H. and Palek, J. (1987). Visualization of the hexagonal lattice in the erythrocyte membrane skeleton. J. Cell Biol. 104, 527-536.

Liu, X., Seno, K., Nishizawa, Y., Hayashi, F., Yamazaki, A., Matsumoto, H., Wakabayashi, T. and Usukura, J. (1994). Ultrastructural localization of retinal guanylate cyclase in human and monkey retinas. Exp. Eye Res. 59, 761-768.

Lolley, R. N. and Racz, E. (1982). Calcium modulation of cyclic GMP synthesis in rat visual cells. Vision Res. 22, 1481-1486.

Lowe, D. G., Dizhoor, A. M., Liu, K., Gu, Q., Spencer, M., Laura, R., Lu, L. and Hurley, J. B. (1995). Cloning and expression of a second photoreceptorspecific membrane retina guanylyl cyclase (RetGC), RetGC-2. Proc. Nat. Acad. Sci. USA 92, 5535-5539.

Miyaguchi, K. and Hashimoto, P. H. (1992). Evidence for the transport of opsin in the connecting cilium and basal rod outer segment in rat retina: rapid-freeze, deep-etch and horseradish peroxidase labelling studies. $J$. Neurocytol. 21, 449-457.

Molday, R. S., Hicks, D. and Molday, L. L. (1987). Peripherin. A rim-specific membrane protein of rod outer segments. Invest. Ophthalmol. Vis. Sci. 28, 50-61.

Molday, R. S. and Molday, L. L. (1987). Difference in the protein composition of bovine retinal rod outer segment disk and plasma membrane isolated by a ricin-gold-dextran density perturbation method. J. Cell Biol. 105, 2589-2601

Nir, I. and Papermaster, D. S. (1983). Differential distribution of opsin in the plasma membrane of frog photoreceptors: an immunocytochemical study. Invest. Ophthalmol. Vis. Sci. 24, 868-878.

Nir, I., Cohen, D. and Papermaster, D. S. (1984). Immunocytochemical localization of opsin in the cell membrane of developing rat retinal photoreceptors. J. Cell Biol. 98, 1788-1795.

Olmsted, J. B. (1986). Analysis of cytoskeletal structures using blot-purified monospecific antibodies. Meth. Enzymol. 134, 467-472.

Palczewski, K., Subbaraya, I., Gorczyca, W. A., Helekar, B. S., Ruiz, C. C., Ohguro, H., Huang, J., Zhao, X., Crabb, J. W., Johnson, R. S., Walsh, K. A., Gray-Keller, M. P., Detwiler, P. B. and Baehr, W. (1994). Molecular cloning and characterization of retinal photoreceptor guanylyl cyclaseactivating protein. Neuron 13, 395-404.

Pardee, J. and Spudich, J. (1982). Purification of muscle actin. Meth. Enzymol. 85, 164-181.

Pepe, I. M., Panfoli, I. and Cugnoli, C. (1986). Guanylate cyclase in rod outer segments of the toad retina. FEBS Lett. 203, 73-76.

Pinder, J. and Gratzer, W. (1983). Structural and dynamic states of actin in the erythrocyte. J. Cell Biol. 96, 768-775.

Pozdnyakov, N., Yoshida, A., Cooper, N. G. F., Margulis, A., Duda, T. Sharma, R. K. and Sitaramayya, A. (1995). A novel calcium-dependent activator of retinal rod outer segment membrane guanylate cyclase. Biochemistry 34, 14279-14283.

Röhlich, P., Adamus, G., McDowell, J. H. and Hargrave, P. H. (1989). Binding pattern of anti-rhodopsin monoclonal antibodies to photoreceptor cells: an immunocytochemical study. Exp. Eye Res. 49, 999-1013.

Rozdzial, M. M., Neighbors, B. W. and McIntosh, J. R. (1990). Blot overlay 


\section{M. A. Hallett and others}

identification of microtubule-binding peptides from bovine brain. Eur. J. Cell Biol. 27-35.

Shyjan, A. W., de Sauvage, F. J., Gillett, N. A., Goeddel, D. V. and Lowe, D. G. (1992). Molecular cloning of a retina-specific membrane guanylyl cyclase. Neuron $\mathbf{9}, 727-737$.

Tam, J. P. (1988). Synthetic peptide vaccine design: synthesis and properties of high-density multiple peptide antigenic peptide system. Proc. Nat. Acad. Sci. USA 85, 5409-5413.

Usukura, J. and Bok, D. (1987). Changes in the localization and content of opsin during retinal development in the rds mutant mouse: immunocytochemistry and immunoassay. Exp. Eye. Res. 45, 501-515.

Van Bergen en Henegouwen, P. M. P., Defize, L. H. K., de Kroon, J., van Damme, H., Verkleij, A. J. and Boonsta, J. (1989). Ligand-induced association of epidermal growth factor receptor to the cytoskeleton of A431 cells. J. Cell. Biochem. 39, 455-465.

Walker, J., Boustead, C. and Witzemann, V. (1984). The 43-K protein, v1, associated with acetylcholine receptor containing membrane fragments is an actin-binding protein. EMBO J. 3, 2287-2290.
Wiegant, F. A. C., Blok, F. J., Defize, L. H. K., Linnemans, W. A. M. Verkley, A. J. and Boonstra, J. (1986). Epidermal growth factor receptors associated to cytoskeletal elements of epidermoid carcinoma (A431) cells. $J$. Cell Biol. 103, 87-94.

Williams, D. S., Arikawa, K. and Paallysaho, T. (1990). Cytoskeletal components of the adherens junctions between the photoreceptors and the supportive Muller cells. J. Comp. Neurol. 295, 155-164.

Williams, D. S. (1991). Actin filaments and photoreceptor membrane turnover. BioEssays 13, 171-178.

Yang, R.-B., Foster, D. C., Garbers, D. L. and Fulle, H.-J. (1995). Two membrane forms of guanylyl cyclase found in the eye. Proc. Nat. Acad. Sci. USA 92, 602-606.

Yarfitz, S. and Hurley, J. B. (1994). Transduction mechanisms of vertebrate and invertebrate photoreceptors. J. Biol. Chem. 269, 14329-14332.

(Received 26 January 1996 - Accepted 18 April 1996) 